\title{
Facile Detection of Proteins on a Solid-Phase Membrane by Direct Binding of Dextran-Based Luminol-Biotin Chemiluminescent Polymer
}

Huan Zhang, ${ }^{1}$ Takayuki Shibata, ${ }^{1}$ Tomasz Krawczyk, ${ }^{1}$ Tsutomu Kabashima, ${ }^{1}$ Jianzhong Lu, ${ }^{2}$ Myung K. Lee, ${ }^{3}$ and Masaaki Kai ${ }^{1,4 *}$

${ }^{1}$ Faculty of Pharmaceutical Sciences, Graduate School of Biomedical Sciences, Nagasaki University, 1-14, Bunkyo-Machi, Nagasaki 852-8521, Japan

${ }^{2}$ School of Pharmacy, Fudan University, Shanghai 200032, China

${ }^{3}$ College of Pharmacy, Chungbuk National University, San4 8, Kaeshin-Dong, Heungduk-Gu, Cheongju 361-763, South Korea

${ }^{4}$ Global Center of Excellence Program at Nagasaki University

* Corresponding author. Tel. and fax : +81-95-819-2438; e-mail: ms-kai@nagasaki-u.ac.jp 


\section{ABSTRACT}

Facile and non-radioactive methods are desired for the sensitive detection and quantification of various proteins. Herein we describe a novel chemiluminescence (CL)-detection method of particular proteins based on direct binding of a dextran-luminol-biotin (DLB) CL polymer to the proteins on a poly(vinylidene difluoride) membrane. Among 32 kinds of the proteins screened, several proteins such as drug-metabolizing enzymes, cytochrome p450 (CYP)1A2, CYP2E1, and CYP3A4 had the ability to bind directly to the DLB polymer. The binding site in the polymer was owing to the framework of the modified dextran, which underwent oxidation and reduction procedures. This interaction might be the comprehensive effect of both electrostatic interaction and steric complementarities. CL intensity of the proteins detected by the polymer could be further enlarged by the mediation of avidin. The proposed CL-imaging method possesses potential as a rapid, facile, inexpensive and selective detection of the proteins.

Keywords: Protein detection, Microchip, Chemiluminescence, Luminol-containing macromolecule

\section{Introduction}

Enzyme-linked immunosorbent assay (ELISA) on 96-wells plastic plate or membrane matrix has been widely used in immunoassay with respect to its specificity and sensitivity. Antibody is indispensable in ELISA; it is routinely utilized as an analytical reagent for specific recognition and binding with an antigen. However, the preparation of a specific antibody to an antigen is expensive, time consuming and laborious, and the antibodies are sensitive to temperature because of irreversible denaturation. Artificial antibody-like receptors, such as aptamer and molecular imprinting polymer (MIP) could be the solution to such problems. Aptamer is a short DNA or 
RNA oligonucleotide that provides specific binding to a target protein. Fifteen years since their discovery, however, aptamers have been obtained only for limited number of proteins because the production of the aptamers is difficult $[1,2]$. MIPs are the synthetic compounds that might be substituted for antibodies in immunoassay; however, the hydrophobic nature and highly cross-linked structure of the polymer limit the access of the large protein molecules to the binding sites of MIPs [3-5].

The possibility of use of peroxidase or metal enzymes has been recently reported for the sensitive chemiluminescence $(\mathrm{CL})$ detection of particular proteins in the ELISA system. It utilizes the fact that the native enzymes such as horse radish peroxidase could catalyze the CL reaction between luminol and hydrogen peroxide $[6,7]$. In this technique, for example, the electrophoresis should be conducted with the usage of non-denatured gel and running at low temperature to keep the proteins active; otherwise CL signal cannot be seen. CL-imaging methods offer many advantages for high-throughput evaluation, high sensitivity, simple instrumentation, and exclusion of the usage of radioisotopes $[8,9]$. We reported a CL immunoassay for the sensitive detection of a CYP3A4 protein utilizing two antibodies and a dextran-luminol-biotin (DLB) polymer [10]. However, our recent experiments have indicated that the DLB polymer directly bound to some proteins on a membrane in the absence of blocking agents of the framework of the DLB polymer and dextran.

In this study, therefore we developed a novel CL-imaging method for particular proteins such as CYP proteins on a PVDF membrane (Fig. 1). The advantage of this method is to permit facile, rapid, inexpensive and sensitive detection for those proteins on a solid-phase membrane, because the DLB polymer as a signal probe indicated the possibility of the direct binding to the target proteins. Many proteins exist in blood plasma, such as complement proteins, proteins for blood coagulation, adhesion proteins, lipoproteins, protease inhibitors, immunoglobulin, hormones, enzymes, disease-related markers, and so on [11]. We screened 32 kinds of commercially available proteins to be detected by the DLB polymer. Among of them, lysozyme, fibroblast growth factor 5 
(FGF5), cytochrome c, $\beta$-nerve growth factor ( $\beta$-NGF), CYP1A2, CYP2E1, CYP3A4, prolactin and concanavalin A exhibited relatively strong interactions with the polymer. Furthermore, several experiments were conducted to clarify the mechanism of the interaction between the DLB polymer and the proteins.
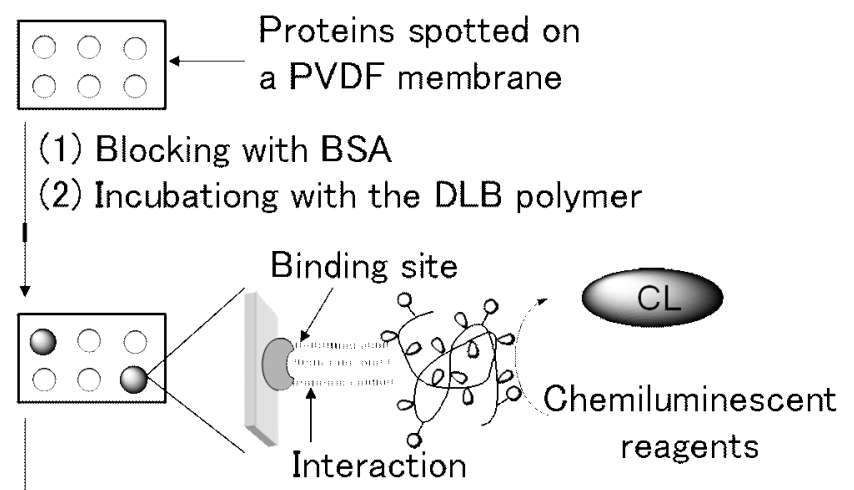

(3) Avidin

(4) Incubation with the DLB polymer

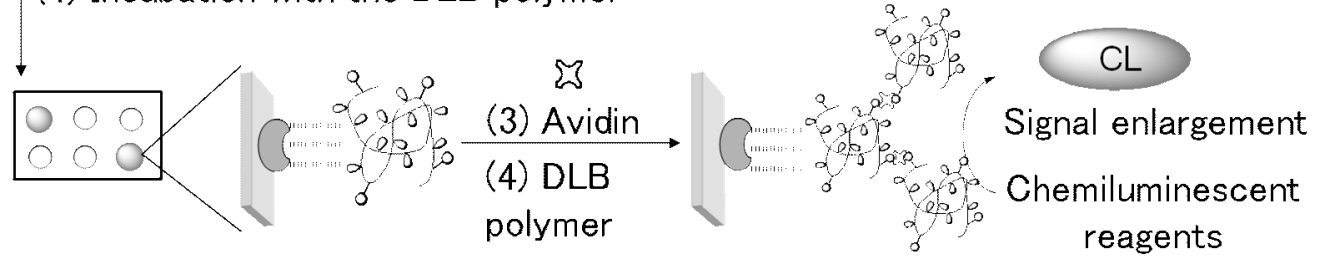

$$
\left(\begin{array}{l}
\text { PVDF } \\
\text { membrane }
\end{array} \text { Protein Dextran } 0 \text { Luminol o Biotin }\right)
$$

Fig. 1. CL detection of a protein on a PVDF membrane by the DLB polymer.

\section{Experimental}

\subsection{Reagents and chemicals}

Dextran T500 (average MW $5 \times 10^{5} \mathrm{Da}$ ) was purchased from Pharmacia Fine Chemicals (Sweden). Sodium periodate and avidin were purchased from Wako (Japan). 6-HydrazidohexylD-biotinamide was purchased from Dojindo (Japan). Luminol and sodium borohydride were purchased from Nacalai Tesque (Japan) and used without further purification. Nylon membranes and poly(vinylidene difluoride) (PVDF) membranes (0.45 $\mu \mathrm{m}$ pore size) were supplied by 
Millipore (Billerica, MA, USA). Tetra-n-butylammonium hydroxide (TBA) was supplied by Sigma-Aldorich (St. Louis, MO, USA). Adrenocorticotropin hormone (40 residues, human) and a peptide fragment (21 residues) of CYP3A4 (human) were purchased from AnaSpec (San Jose, CA, USA). Growth hormone (human recombinant) and parathyroid hormone (human recombinant) were purchased from Atgen (Korea). Mouse $\beta$-nerve growth factor ( $\beta$-NGF) was supplied by Austral Biologicals (San Ramon, CA, USA). A peptide fragment (12 residues) of CYP1A2 (human) was supplied by Biomol (USA). Ceruloplasm (human plasma), concanavalin A (canavalia ensiformis), cytochrome c (equine heart), fibrinogen (human plasma), follicle-stimulating hormone (human pituitary), peanut lectin (arachis hypogaea), luteinizing hormone (human pituitary), serum amyloid A (human serum), superoxide dismutase (human recombinant), thrombin (bovine), thyroglobulin (human thyroid), transferring, $\beta_{2}$-microglobulin (human), and haptoglobin were purchased from Calbiochem (Germany). Bovine serum albumin (BSA) was purchased from Nacalai Tesque (Japan). Hemoglobin (human) was purchased from Nutritional Biochemicals (USA). CYP1A2 (human recombinant), CYP2E1 (human recombinant), CYP3A4 (human recombinant), monoclonal anti-CYP1A2 antibody (mouse anti-human), and polyclonal anti-CYP1A2 antibody (rabbit anti-human) were supplied by Oxford Biochemical Research (USA). Fibroblast growth factor 5 (FGF5, human recombinant) and prolactin (mouse recombinant) were supplied by R\&D Systems (USA). Bovine serum albumin (BSA), lysozyme (chicken egg white), myoglobin (equine skeletal muscle), $\alpha$-amylase (aspergillus oryae), and $\beta$-lactoglobulin (bovine milk) were purchased from Sigma (St. Louis, MO, USA).

\subsection{Synthesis of a DLB polymer and its related compounds (Fig. 2)}

Dextran T500 (400 mg) with ca. $500 \mathrm{kDa}$ in average molecular weight was dissolved in water $(40 \mathrm{~mL})$ followed by precipitating with methanol. The precipitate was filtered, re-dissolved in water $(60 \mathrm{~mL})$, and then sodium periodate $(317 \mathrm{mg})$ was added. The reaction mixture was stirred at room temperature until the $310 \mathrm{~nm}$ UV-absorption band corresponding to sodium periodate 
disappeared. Then, the reaction mixture was poured into methanol $(300 \mathrm{~mL})$, the precipitate of partially oxidized dextran (ox-Dex) was filtered off and used in the next step.

To the oxidized dextran was added dimethyl sulfoxide (DMSO) $(40-80 \mathrm{~mL})$ and the mixture heated at $100{ }^{\circ} \mathrm{C}$ to dissolve the oxidized dextran completely. 6-Hydrazidohexyl-D-biotinamide $(30 \mathrm{mg}$ ) was then added to the solution and allowed to stir at room temperature for $3 \mathrm{~h}$. Glacial acetic acid $(16 \mathrm{~mL})$ and luminol $(240 \mathrm{mg})$ were subsequently added into the reaction mixture and left stirring at $60{ }^{\circ} \mathrm{C}$ overnight. The mixture was poured into methanol $(400 \mathrm{~mL})$. Methanol was removed from the precipitate by careful decantation, and then another $500 \mathrm{~mL}$ of methanol was added to the precipitate. After stirring for $30 \mathrm{~min}$, a yellowish powder (DLB polymer) of the conjugates was collected by filtration. In the case of the synthesis of the dextran-based compound containing only luminol (DL), the addition of 6-hydrazidohexyl-D-biotinamide was omitted.

The modified dextran polymer was dissolved in ethyleneglycol $(20-60 \mathrm{~mL})$. Excess of sodium borohydride $(870 \mathrm{mg})$ was added into the ice-cooled reaction mixture and the mixture was left stirring at room temperature for $4 \mathrm{~h}$. Then reaction was continued at $4{ }^{\circ} \mathrm{C}$ overnight without stirring. The desired polymer was reprecipitated by acetone $(200 \mathrm{~mL})$, washed three times with methanol $(300 \mathrm{~mL})$ to remove the unreacted biotin and luminol. The precipitate was then dried in vacuo overnight. Three dextran-related compounds were obtained: oxidized and reduced dextran (ox-red-Dex) as a white powder (150-200 $\mathrm{mg}), \mathrm{DL}$ as a pale yellow powder (250-300 $\mathrm{mg}$ ) and DLB polymer as a pale yellow powder (150-200 mg).

\subsection{CL detection of DLB polymer on a nylon membrane}

Aqueous solution of DLB polymer was spotted on a nylon membrane and dried in vacuo for 10 $\min$. The membrane was then washed with methanol $(2.0 \mathrm{~mL})$ at $37{ }^{\circ} \mathrm{C}$ for $5 \mathrm{~min}$, and dried again in vacuo for $10 \mathrm{~min}$. The membrane was immersed for $10 \mathrm{~s}$ in a mixture consisting of $700 \mu \mathrm{L}$ of acetonitrile, $300 \mu \mathrm{L}$ of $0.5 \mathrm{M}$ TBA and $50 \mu \mathrm{L}$ of $30 \%$ hydrogen peroxide for the $\mathrm{CL}$ reaction. The CL-imaging detection was conducted by a CCD camera (Light capture AE-6971/2 device, ATTO, 
Japan) for 2.0 min of exposure time.

\subsection{Binding constant of DLB polymer to avidin}

A PVDF membrane was dotted with $3.0 \mu \mathrm{L}$ of $100 \%$ ethanol followed by spotting of avidin $(0.5 \mathrm{nM})$ in water. The membrane was dried in vacuo at $37{ }^{\circ} \mathrm{C}$ for $10 \mathrm{~min}$. The PVDF membrane was incubated with different concentrations of DLB polymer $\left(0.05-0.15 \mathrm{mg} \mathrm{mL}^{-1}\right)$ in $2.0 \mathrm{~mL}$ of 25 $\mathrm{mM}$ Tris buffer $(\mathrm{pH} 7.2)$ at $37{ }^{\circ} \mathrm{C}$ for $30 \mathrm{~min}$. The membrane was washed twice at $37{ }^{\circ} \mathrm{C}$ with $4.0 \mathrm{~mL}$ of $10 \mathrm{mM}$ phosphate buffer saline (PBS) containing $0.15 \%(\mathrm{w} / \mathrm{v})$ Triton X-100. After the consecutive washing of the membrane with $2.0 \mathrm{~mL}$ of $75 \%(\mathrm{v} / \mathrm{v})$ methanol, the membrane was dried in vacuo at $37{ }^{\circ} \mathrm{C}$ for $10 \mathrm{~min}$. The $\mathrm{CL}$ reaction and imaging detection were performed as described above. Using Scatchard plot method, the binding constant $K$ of the polymer to avidin and the binding molar ratio of avidin to the polymer was calculated.

\subsection{Detection of proteins on a PVDF membrane by DLB polymer}

A PVDF membrane was spotted by ethanol $(3.0 \mu \mathrm{L})$ followed by spotting of various proteins in $25 \mathrm{mM}$ Tris buffer (pH 7.2). The membrane was dried in vacuo at $37{ }^{\circ} \mathrm{C}$ for $30 \mathrm{~min}$. The membrane was blocked with $3.0 \mathrm{~mL}$ of $3 \%$ BSA in $10 \mathrm{mM}$ PBS (pH 7.2), followed by washing with $3.0 \mathrm{~mL}$ of the PBS. The membrane was incubated in a mixture $(2.0 \mathrm{~mL})$ of $2.0 \mathrm{mg}$ DLB polymer and $4.0 \mathrm{mg}$ BSA in $25 \mathrm{mM}$ Tris buffer $(\mathrm{pH} 7.2)$ at $37{ }^{\circ} \mathrm{C}$ for $30 \mathrm{~min}$. After the reaction, the membrane was washed three times with $5.0 \mathrm{~mL}$ of $10 \mathrm{mM}$ PBS containing $1 \%$ Triton $\mathrm{X}-100$, followed by washing the membrane with $2.0 \mathrm{~mL}$ of $75 \%$ methanol. The membrane was dried in vacuo at $37^{\circ} \mathrm{C}$ for $20 \mathrm{~min}$. The CL reaction and imaging detection were performed as described above. 


\section{Results and discussion}

Prior to the investigation of the direct binding of our DLB polymer to proteins, we successively synthesized a series of dextran-related compounds (Fig. 2). The synthetic route to the DLB polymer was consisted of 4 steps: partial oxidation of dextran for oxidized dextran (ox-Dex), coupling between ox-Dex and luminol for ox-Dex containing luminol (DL), biotinylation of DL without reduction for ox-Dex containing luminol and biotin (pre-DLB polymer), and reduction of pre-DLB polymer for the DLB polymer. In order to evaluate the protein-binding mechanism of the DLB polymer, ox-red-Dex was synthesized by reduction of ox-Dex without luminol and biotin.

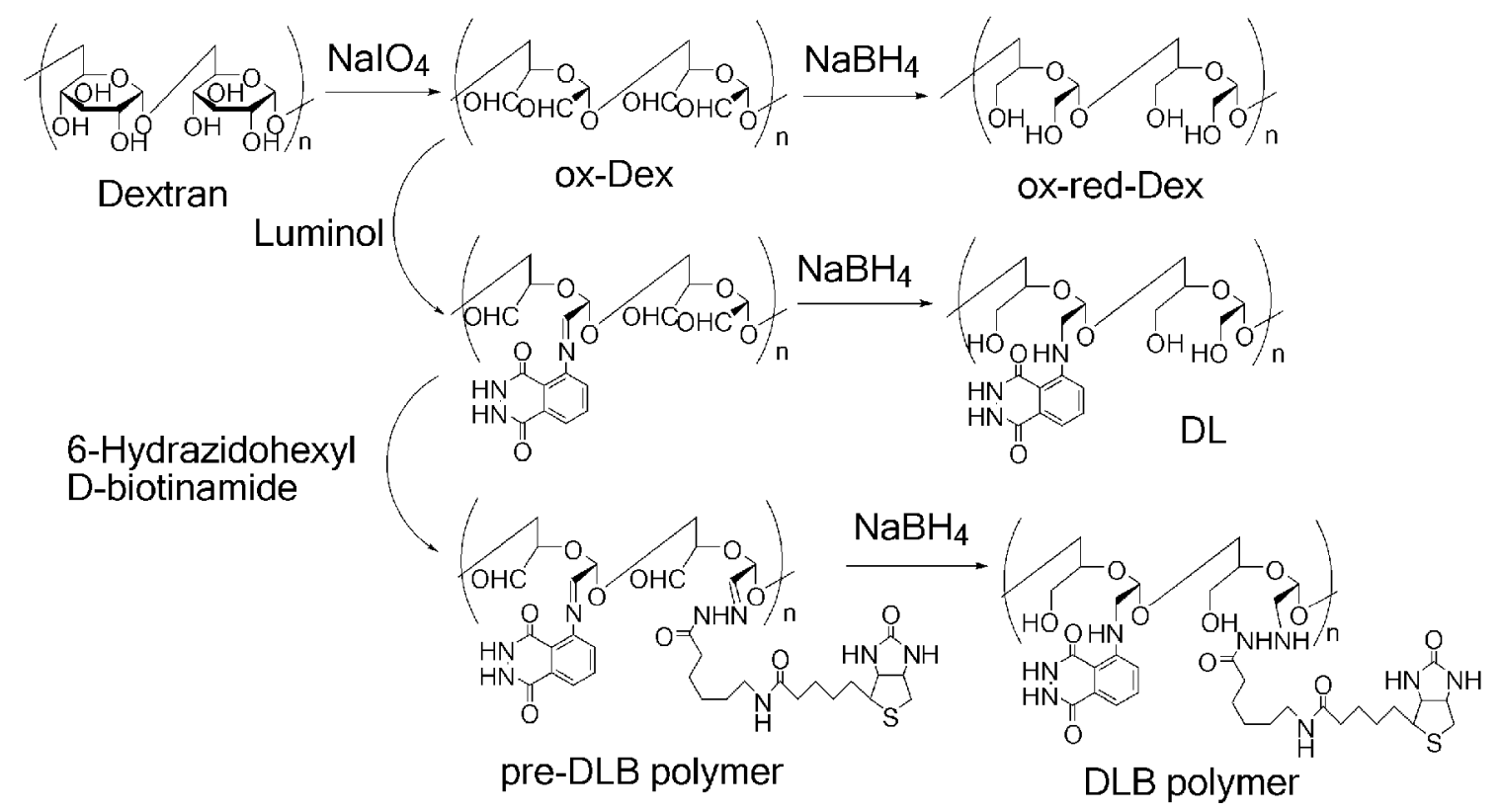

Fig. 2. Synthetic pathway of dextran-based polymers.

According to the elemental analysis data, the atomic composition of the synthesized DLB polymer and its molecular weight can be deduced. The atomic composition of the synthesized DLB polymer was $43 \% \mathrm{C}, 5.8 \% \mathrm{H}, 4.4 \% \mathrm{~N}$, and $0.17 \% \mathrm{~S}$, and its molecular weight was found to be approximately $6.3 \times 10^{5} \mathrm{Da}$. These data indicate that this polymer contained approximately 560 and 34 molecules of luminol and biotin, respectively in a dextranT500 molecule (3100 glucose units). The aqueous solution of the DLB probe gave approximately 300 times higher CL intensity at the same amount $(1.0 \mathrm{fmol})$ of free luminol. It was found that the increased 
introduction of luminol gives more intense CL for the probe.

The CL intensity from the DLB polymer was measured by using different amounts of the polymer immobilized on a nylon membrane. The DLB polymer could be visualized by means of CL detection. The CL intensity was proportional to the amount of the polymer $[y=0.1583 x-0.243$, $\mathrm{r}^{2}=0.9965$; where $\mathrm{y}=\mathrm{CL}$ intensity $\left(\times 10^{6}\right), \mathrm{x}=$ amount of the DLB polymer (ng) and $\mathrm{r}^{2}=$ correlation coefficient]. Therefore, a large number of luminol molecules were chemically introduced into the polymer and the bound luminol did not lose from the polymer during the assay treatment. Next we investigated the binding ability of the polymer to avidin. It was shown that the CL intensity increased with the increased amounts of the polymer. The result indicates that biotin moieties in the polymer can bind to avidin. By using Scatchard plot method, the binding constant and the binding molar ratio of avidin to DLB polymer were about $5.1 \times 10^{6} \mathrm{M}^{-1}$ and 60 , respectively.

The DLB polymer was originally used for the detection of CYP3A4 by binding to biotin-containing anti IgG antibody (second antibody) that bound to anti CYP3A4 antibody (first antibody) binding to CYP3A4 in immunoassay. When CYP3A4 blotted on a PVDF membrane was treated with a mixture of streptavidin, BSA, dextran, ox-red-Dex, the antibodies and the DLB polymer, the detection of CYP3A4 could be achieved in the presence of the antibodies (Fig. 3a). On the other hand, negligible light was emitted from the protein in the absence of the antibodies (Fig. 3b). Although the polymer could be applicable to immunoassay for the sensitive and specific detection of a target protein [10], in the absence of blocking substances such as ox-red-Dex and dextran, CL emission from CYP3A4 was observed when the membrane was incubated with a mixture of the DLB polymer and BSA (Fig. 3c). This result indicated that the DLB polymer has a binding site in the molecule. 


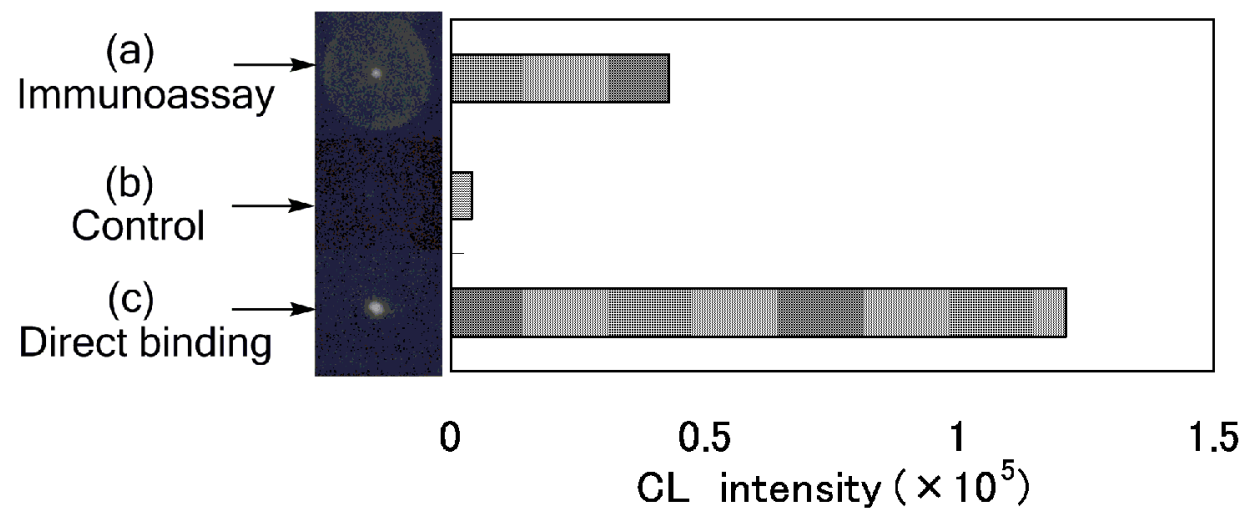

Fig. 3. CL detections of CYP3A4 by immunoassay using anti CYP3A4 antibody, biotin-containing anti IgG antibody, and by direct binding of DLB polymer. CYP3A4 (200 ng) spotted on a PVDF membrane was incubated at $37{ }^{\circ} \mathrm{C}$ for $2 \mathrm{~h}$ (a) with the first and second antibodies, or (b) without the antibodies in $10 \mathrm{mM}$ PBS for control. After washing, the protein was detected by $\mathrm{CL}$ reaction after the incubation at $37^{\circ} \mathrm{C}$ for $30 \mathrm{~min}$ with a mixture [DLB polymer (4 $\mathrm{mg}$ ), streptavidin (4 mg), BSA (6mg), dextran (6 mg) and ox-red-Dex (20 mg) in $2 \mathrm{~mL}$ of $10 \mathrm{mM}$ PBS] for immunoassay, and (c) for the direct binding of DLB polymer, the membrane was incubated with a mixture [DLB polymer $(4 \mathrm{mg})$ and BSA $(6 \mathrm{mg})$ in $2 \mathrm{~mL}$ of $10 \mathrm{mM}$ PBS], and after washing, the protein was detected by CL reaction.

The above findings encouraged us to apply the DLB polymer to detect directly various proteins on a PVDF membrane, which included CYP proteins, carbohydrate-binding proteins, hormones, and plasma proteins (Table 1). The data indicated that CYP1A2 had the highest affinity to the polymer. CYP2E1, CYP3A4, lysozyme, FGF5, cytochrome c, $\beta$-NGF, and prolactin showed the strong CL. Hemoglobin, serum amyloid A and concanavalin A exhibited moderate binding affinity, while no signal was observed with the other proteins and peptides. Therefore, these bindings of the polymer to the proteins are not due to the molecular size of the proteins. It seems that the polymer might bind to particular proteins with relatively high isoelectronic point $(\mathrm{pI})$, since there were several proteins with high pI values showing no affinity to the polymer, and 
concanavalin A even with a low pI value of 5 slightly bound to the polymer. No specific reason of the preference of the polymer to proteins can be clarified at this stage. However, interesting results were obtained from two shorter fragments of CYP1A2 (12 residues) and CYP3A4 (21 residues). No CL signals from these fragments were observed, even though the fragments have higher pI values. The results indicated that a specific region of the polymer participates in the protein binding.

It should be noted that the DLB polymer did not bind to the immunoglobulin proteins such as monoclonal and polyclonal anti-CYP1A2 antibodies, as shown in Table 1. By utilizing this characteristic, the development of a new detection method specific for the CYP proteins will be possible, in which several CYP proteins are individually recognized and captured by each anti-CYP antibody immobilized separately on a solid-phase membrane, following the direct detection of the CYP proteins on the membrane by the DLB polymer.

Table 1 The list of the proteins used in this study and their corresponding CL intensities.

\begin{tabular}{lccc}
\hline Protein (100 ng) & $\begin{array}{c}\text { MW } \\
\left(\times 10^{3} \text { Dalton }\right)\end{array}$ & pI & CL intensity $\%^{\mathrm{c}}$ \\
\hline Lysozyme & $14^{\mathrm{a}}$ & $11.0^{\mathrm{a}}$ & 30 \\
Fragment (12 residues) of CYP1A2 & 1.3 & $10.0^{\mathrm{b}}$ & 0 \\
Fragment (21 residues) of CYP3A4 & 2.6 & $9.7^{\mathrm{b}}$ & 0 \\
FGF5 & 27 & $9.4^{\mathrm{b}}$ & 88 \\
Cytochrome c & 13 & $9.4^{\mathrm{a}}$ & 17 \\
$\beta$-NGF & $27^{\mathrm{a}}$ & $9.3^{\mathrm{a}}$ & 35 \\
CYP1A2 & 58 & $9.2^{\mathrm{b}}$ & 100 \\
Luteinizing hormone & 29 & $8.8^{\mathrm{a}}$ & 0 \\
CYP2E1 & 53 & $8.3^{\mathrm{b}}$ & 57 \\
CYP3A4 & 66 & $8.3^{\mathrm{b}}$ & 23 \\
Adrenocorticotropin hormone (40 residues) & 4.5 & $8.1^{\mathrm{b}}$ & 0 \\
Parathyroid hormone & 9.6 & $8.1^{\mathrm{a}}$ & 0 \\
Myoglobin & $18^{\mathrm{a}}$ & $8.1^{\mathrm{a}}$ & 0 \\
Hemoglobin & $65^{\mathrm{a}}$ & $6.9^{\mathrm{a}}$ & 7 \\
Monoclonal anti-CYP1A2 antibody & $150^{\mathrm{a}}$ & $6.5^{\mathrm{a}}$ & 0 \\
Peanut lectin & 110 & $6.5^{\mathrm{a}}$ & 0
\end{tabular}


Prolactin

Serum amyloid A

Fibrinogen

Follicle stimulating hormone

Polyclonal anti-CYP1A2 antibody

$\alpha$-Amylase

Thrombin

$\beta_{2}$-Microglobulin

Transferrin

$\beta$-Lactoglobulin

Concanavalin A

Growth hormone

BSA

Superoxide dismutase

Thyroglobulin

Ceruloplasm

Haptoglobin
23

12

341

36

$150^{\mathrm{a}}$

$45^{\text {a }}$

34

12

80

$18^{\mathrm{a}}$

104

20

66

32

660

134

86 $6.1^{\text {a }}$

$5.9^{\mathrm{b}}$

$5.6^{\mathrm{a}}$

$5.6^{\mathrm{a}}$

$5.5^{\mathrm{a}}$

$5.5^{\mathrm{a}}$

$5.5^{\mathrm{a}}$

$5.5^{\mathrm{a}}$

$5.3^{\mathrm{a}}$

$5.1^{\mathrm{a}}$

$5.0^{\mathrm{a}}$

$5.0^{\mathrm{a}}$

$4.8^{\mathrm{a}}$

$4.8^{\mathrm{a}}$

$4.5^{\mathrm{a}}$

$4.4^{\mathrm{a}}$

$4.2^{\mathrm{a}}$

37

8

0

0

0

0

0

0

0

0

13

${ }^{\mathrm{a}} \mathrm{MW}$ and $\mathrm{pI}$ were obtained from a laboratory book. ${ }^{\mathrm{b}} \mathrm{pI}$ was calculated from the amino acid sequence by the computer software on internet. Other MW and pI that do not labeled were obtained from the product description of the company. $\quad{ }^{\mathrm{c}} \mathrm{CL}$ intensity obtained from CYP1A2 was taken as a reference $(100 \%)$.

We investigated the interaction between cytochrome c (cyt c) and the DLB polymer by using gel filtration liquid chromatography (GFLC). Cyt c has its maximum absorption at $408 \mathrm{~nm}$, while the DLB polymer has no absorption at $408 \mathrm{~nm}$ (Fig. $4 \mathrm{a}$ and $4 \mathrm{~b}$ ). On the other hand, the DLB polymer showed two fluorescence (FL) peaks at the retention times of $13.5 \mathrm{~min}$ and $20.5 \mathrm{~min}$. These FL peaks were identified as the luminol moiety in the macromolecular polymer (13.5 min) and free luminol at 20.5 min. However, the small amount of free luminol (approximately 1\%, w/w) did not interfere with the detection of a target protein on a membrane, because it could be sufficiently removed from the membrane by washing with PBS containing $1 \%$ Triton X-100 and $75 \%$ methanol.

When the DLB polymer was mixed with cyt c before injection to GFLC, a new broad peak was 
detected at the retention time of 12.5 min with both the detections of absorbance at $408 \mathrm{~nm}$ and FL (Fig. 4c), indicating the formation of a complex between cyt $\mathrm{c}$ and the DLB polymer. In order to confirm the binding site of the DLB polymer to the protein, we synthesized two compounds similar to the DLB polymer; one was DL that does not contain biotin, and the other one was ox-red-Dex in which the dextran was oxidized and reduced without biotin and luminol. These frameworks of the DLB polymer were used to evaluate their binding abilities to cyt $\mathrm{c}$. Figure $4 \mathrm{~d}$ shows that DL could bind to cyt $\mathrm{c}$, indicating that the biotin moiety in the polymer was not the binding site for the protein. From Figure 4e, it is clear that ox-red-Dex had the ability to bind to cyt $\mathrm{c}$, suggesting that the luminol moiety in the polymer did not bind to the protein. As shown in Fig. 4f, the pristine dextran did not bind to the protein. These results lead to the conclusion that the framework produced by oxidization and reduction of dextran has the ability to interact with the protein.
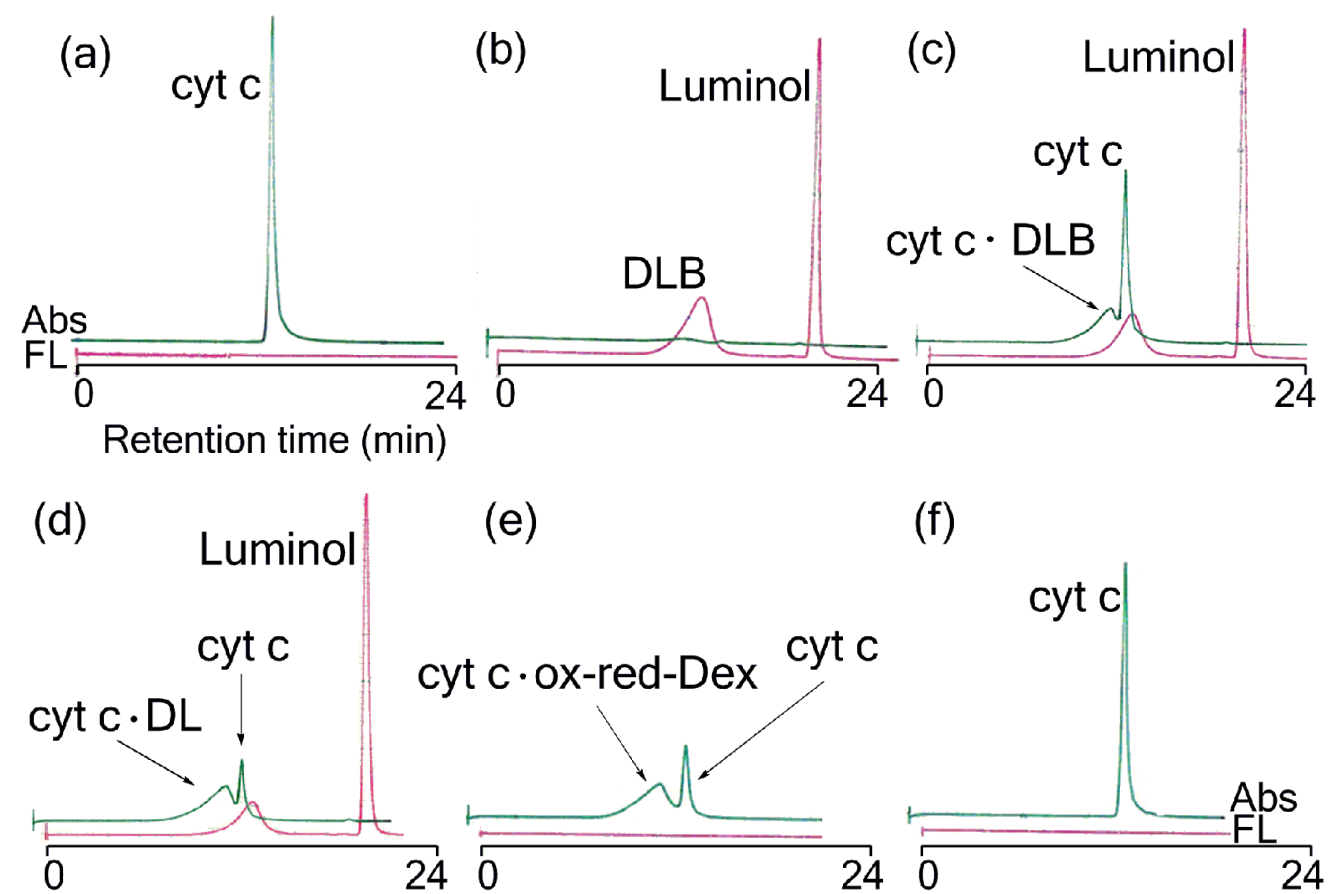

(e)

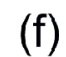

Fig. 4. GFLC identification of the interaction between the DLB polymer and cytochrome c. Samples: (a) $1 \mathrm{mg} \mathrm{mL}^{-1}$ cytochrome c (cyt c); (b) $1 \mathrm{mg} \mathrm{mL}^{-1}$ DLB polymer (DLB); (c) a mixture of $1 \mathrm{mg} \mathrm{mL}^{-1} \mathrm{DLB}$ and $1 \mathrm{mg} \mathrm{mL}^{-1}$ cyt c at $37{ }^{\circ} \mathrm{C}$ for $1 \mathrm{~h}$; (d) a mixture of $1 \mathrm{mg} \mathrm{mL}^{-1} \mathrm{DL}$ and $1 \mathrm{mg}$ $\mathrm{mL}^{-1}$ cyt c at $37{ }^{\circ} \mathrm{C}$ for $1 \mathrm{~h}$; (e) a mixture of $1 \mathrm{mg} \mathrm{mL}^{-1}$ ox-red-Dex and $1 \mathrm{mg} \mathrm{mL}^{-1}$ cyt c at $37{ }^{\circ} \mathrm{C}$ 
for $1 \mathrm{~h}$; (f) a mixture of $1 \mathrm{mg} \mathrm{mL}^{-1}$ pristine dextran and $1 \mathrm{mg} \mathrm{mL}^{-1}$ cyt $\mathrm{c}$ at $37{ }^{\circ} \mathrm{C}$ for $1 \mathrm{~h}$. GFLC conditions: injection volume, $10 \mu \mathrm{L}$; column, TSK gel T2000SW; eluent, 20 mM PBS (pH 7.2); flow rate, $1.0 \mathrm{~mL} / \mathrm{min}$; absorbance detection $(\mathrm{Abs}), \lambda \mathrm{ab}=408 \mathrm{~nm}$; FL detection, $\lambda$ excitation=254 $\mathrm{nm}$ and $\lambda$ emission$=370-430 \mathrm{~nm}$.

The protein binding of a series of dextran-related compounds was further evaluated employing CYP2E1 spotted on a PVDF membrane. Figure 5a indicates that CL intensity obtained from the conjugate of DLB or DL polymer with CYP2E1 was nearly the same. The results confirm that biotin and luminol moieties in the polymer had no influence on the interaction with CYP2E1.

We synthesized pre-DLB polymer having many free aldehyde groups in the framework. The pre-DLB polymer gave only less than half of the CL intensity obtained with the DLB polymer for the detection of CYP2E1 (Fig. 5a). In addition, the background signal was increased with the pre-DLB polymer. Therefore, this pre-DLB polymer was not used for the detection. We thought first that there would be aldehyde groups in the DLB polymer left unreacted, since the reaction of the aldehyde group in the polymer with $\mathrm{NH}_{2}$ group in the protein might result in non-specific binding of the polymer to any proteins. However, the DLB polymer definitely showed the preference to the particular proteins (Table 1).

We additionally investigated to clarify the mechanism of their interaction. We considered that the binding force might be an electrostatic one. We measured the zeta potential of the DLB polymer on a Malvern zetasizer. The average zeta potential of the polymer was about $-27.32 \mathrm{mV}$ $(n=3)$ in the experimental condition of $25 \mathrm{mM}$ Tris buffer at $\mathrm{pH}$ 7.2. The pI values of CYP1A2, FGF5, CYP2E1, $\beta$-NGF, lysozyme, CYP3A4, and cytochrome c were 9.2, 9.4, 8.3, 9.3, 11, 8.3, and 9.4, respectively. In the experimental $\mathrm{pH}$ region, these proteins should have positive charges. The DLB polymer was allowed to react with CYP2E1 in various concentrations of the binding buffer, Tris buffer at pH 7.2 (Fig. 5b). Higher concentration of the buffer resulted in lower binding ability of the DLB polymer to the protein. Figure $5 \mathrm{c}$ shows that $\mathrm{pH}$ of the binding buffer affected 
the interaction between the polymer and the protein. We noticed that the binding between the DLB polymer and CYP2E1 is stronger at a neutral $\mathrm{pH}$. Therefore, the binding of the polymer would be one of results of an electrostatic interaction between negative charges of the polymer and positive charges of the protein. However, as shown in Table 1, some proteins such as luteinizing hormone (pI 8.8), adrenocorticotropin hormone (40 residues, pI 8.1), parathyroid hormone (pI 8.1) and myoglobin (pI 8.1), did not bind to the polymer, even that they had positive charges at the neutral condition. In addition, other proteins such as concanavalin A (pI 5), serum amyloid A (pI 5.9), prolactin (pI 6.1), and hemoglobin (pI 6.9) interacted with the polymer, despite they have negative charges in the binding buffer. Concanavalin A was a carbohydrate-binding protein, and thus it might be absorbed on the polysaccharide groups in the polymer. Although peanut lectin (pI 6.5) was also carbohydrate-binding proteins, the protein did not interact with the polymer. Therefore, the binding between the polymer and the particular proteins might be caused by not only the electrostatic interaction but also another interaction.

Another hypothesis was the steric complementarity that played an important role in the interaction between the DLB polymer and the proteins. Since the framework of the polymer has a linear long chain structure, its chain having many hydroxyl groups after oxidation and reduction of dextran might be able to form a special anchoring site or a binding domain, which led to the specific binding of the DLB polymer to the particular proteins. The structural complementarity might be the other binding force between the DLB polymer and the proteins.

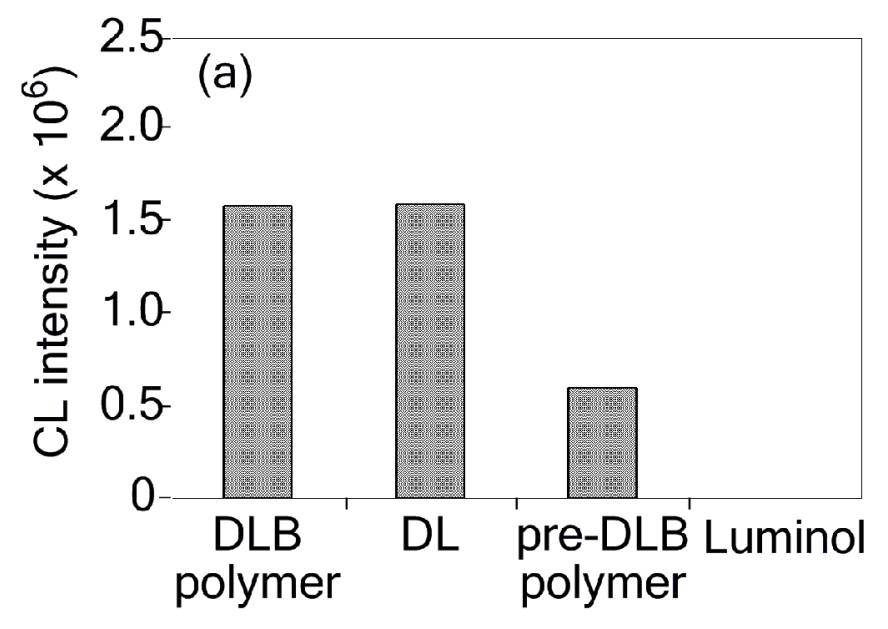



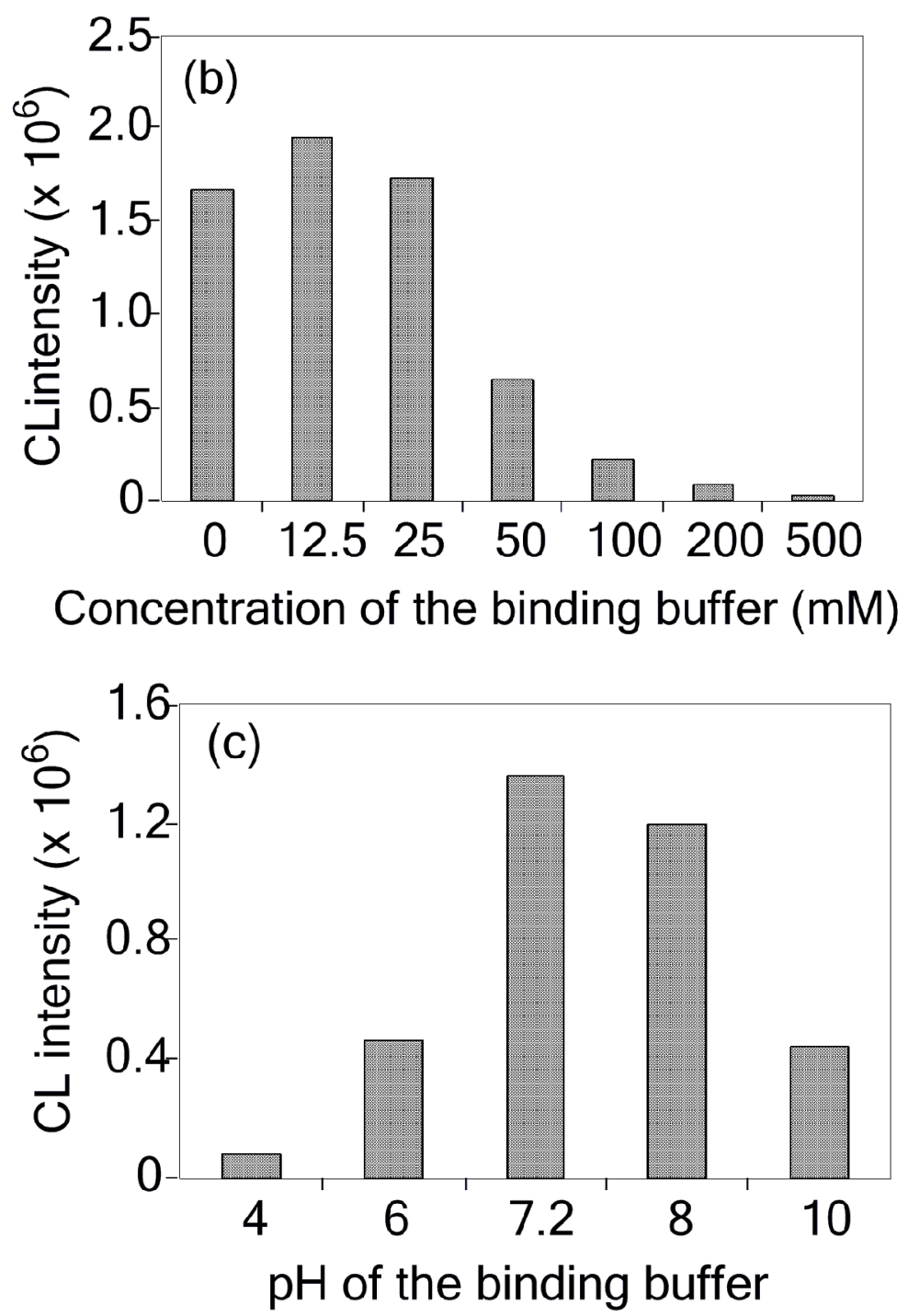

Fig. 5. (a) Direct detection of CYP2E1 with a series of dextran-luminol-related compounds. CYP2E1 protein $(200 \mathrm{ng})$ spotted on a PVDF membrane, and the membrane was incubated with the DLB polymer, DL, pre-DLB polymer or free luminol in $2.0 \mathrm{~mL}$ of $25 \mathrm{mM}$ Tris buffer (pH 7.2) at $37{ }^{\circ} \mathrm{C}$ for $30 \mathrm{~min}$. (b) The influence of the concentration of the binding buffer. CYP2E1 protein (200 ng) was spotted on a PVDF membrane, and the membrane was incubated with the DLB polymer in different concentrations of Tris buffer of $\mathrm{pH} 7.2$ at $37^{\circ} \mathrm{C}$ for $30 \mathrm{~min}$. (c) The influence of $\mathrm{pH}$ of the binding buffer. CYP2E1 protein (200 $\mathrm{ng}$ ) was spotted on a PVDF membrane, and the membrane was incubated with the DLB polymer in different pHs of $25 \mathrm{mM}$ Tris buffer at $37^{\circ} \mathrm{C}$ for $30 \mathrm{~min}$. 
The efficiency of the DLB polymer on the binding to the proteins was investigated by the CL detection of different amounts of a protein absorbed onto a PVDF membrane. As shown in Fig. 6, the proteins of CYP1A2, CYP2E1 and FGF5 were detected and visualized by the DLB polymer. The logarithm of CL intensity was proportional to the amounts of the protein spotted on the membrane $\left[\mathrm{y}=0.0131 \mathrm{x}+4.0504, \mathrm{r}^{2}=0.9773\right.$ for CYP1A2; $\mathrm{y}=0.0142 \mathrm{x}+3.8593, \mathrm{r}^{2}=0.949$ for FGF5; $y=0.0081 x+4.121, r^{2}=0.9366$ for CYP2E1; whereas $y=\ln (C L$ intensity), $x=$ amount of protein (ng) and $\mathrm{r}^{2}=$ correlation coefficient].

(a)
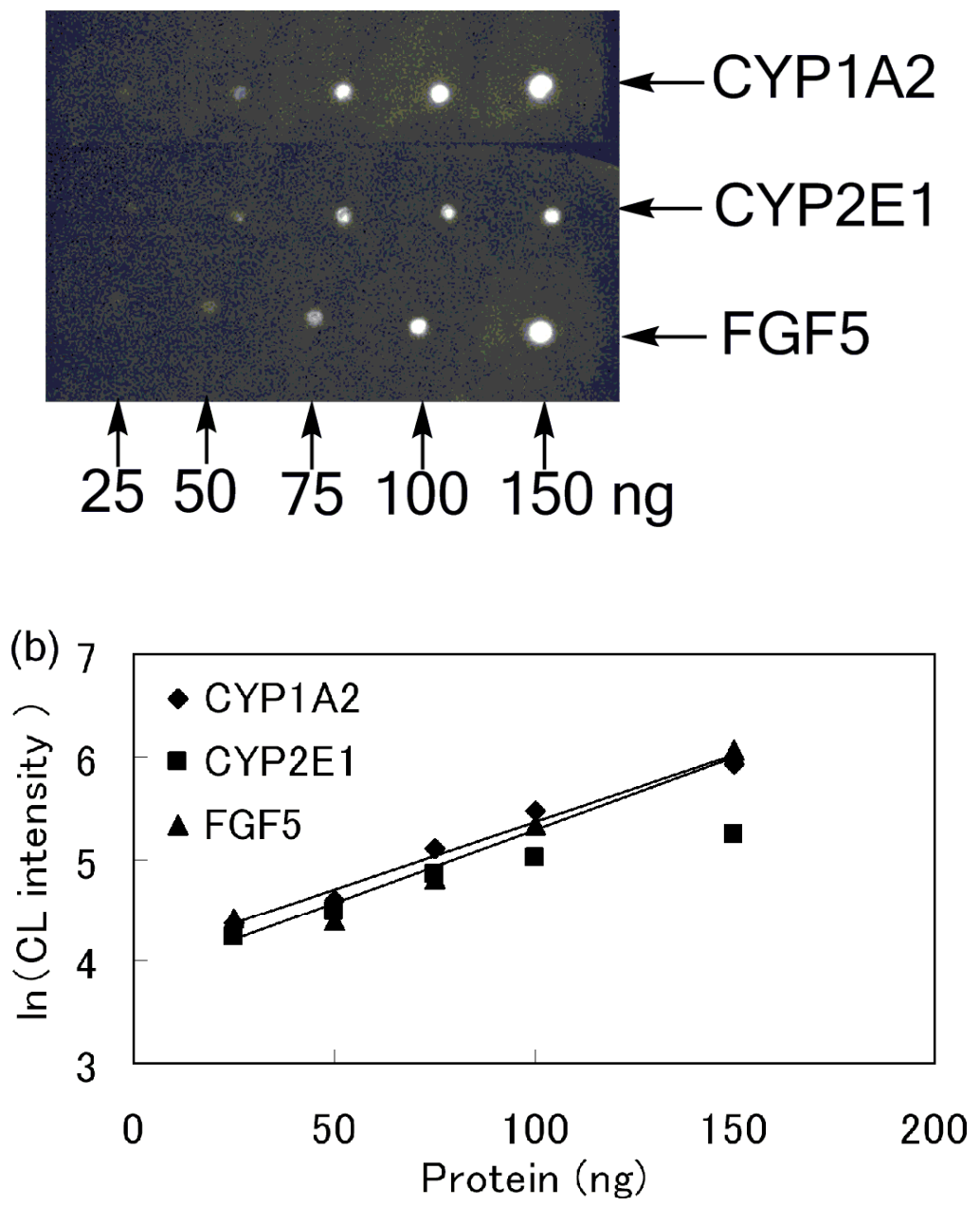

Fig. 6. (a) CL imaging and (b) calibration curves of proteins on a PVDF membrane. CYP1A2, CYP2E1 and FGF5 (25 -150 ng each) were spotted on a PVDF membrane, and the membrane was detected by the DLB polymer. 
The DLB polymer contains numerous biotin moieties which can bind specifically to avidin protein. Therefore, after the binding of the polymer to the proteins, the addition of avidin followed by further addition of the polymer might lead to the formation of a polymer-avidin assembly, which would result in the enlargement of the CL intensity, as shown in Fig. 1. The efficiency of the assembly was investigated with different amounts of CYP2E1 spotted on a PVDF membrane (Fig. 7). When the membrane spotted with CYP2E1 was treated with avidin and the DLB polymer, the CL signal was increased with the increasing amounts of avidin. These results indicate that avidin was unambiguously involved in the polymeric polymer assembly. Therefore, the enhancement of the CL signal was successfully achieved by the addition of avidin into the polymer solution.

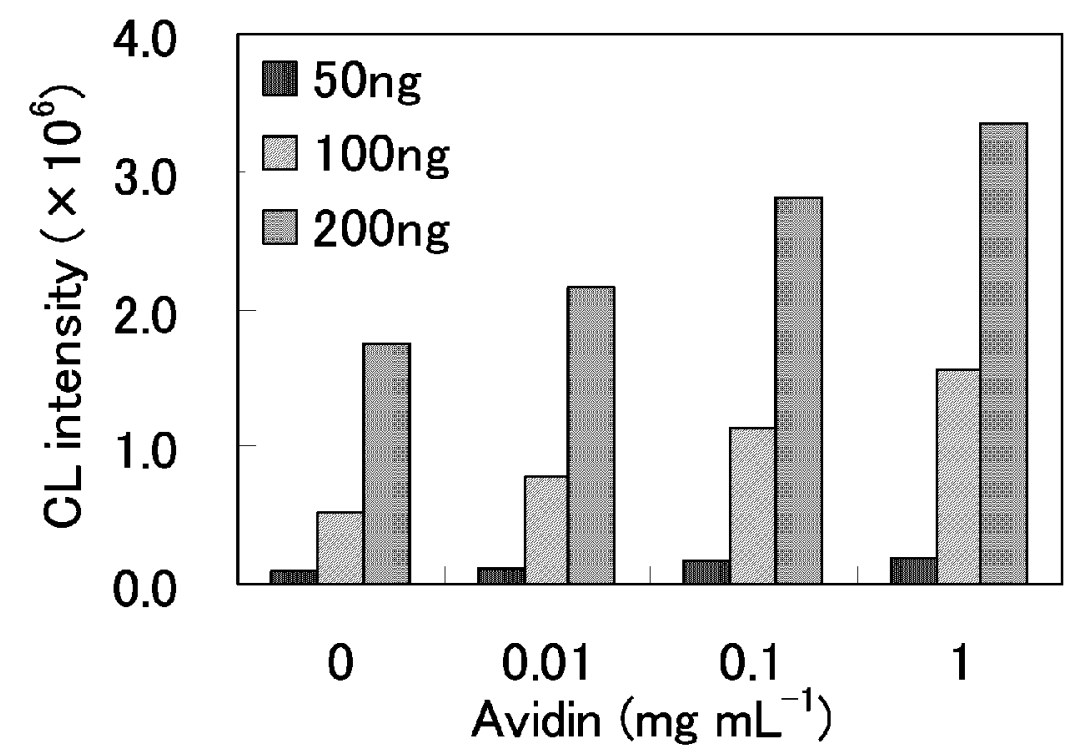

Fig. 7. The effect of avidin concentration on the enhancement of CL signal from CYP2E1 bound to the DLB polymer. CYP2E1 protein $(50,100$ or $200 \mathrm{ng})$ was spotted on a PVDF membrane. After the binding reaction with the DLB polymer, the membrane was additionally incubated with avidin $\left(0.01-1 \mathrm{mg} \mathrm{mL}^{-1}\right)$ at $37{ }^{\circ} \mathrm{C}$ for $10 \mathrm{~min}$ in order to form the avidin-DLB polymer assembly. 


\section{Conclusions}

The proposed CL-imaging method provided the facile detection for several proteins such as CYP1A2, CYP2E1 and CYP3A4 on a PVDF membrane by using the DLB polymer. This polymer exhibited sufficient solubility in water, strong CL signal and high ability to bind to avidin. After screening various proteins, we found that the CYPs, lysozyme, FGF5, cytochrome $\mathrm{c}, \beta-\mathrm{NGF}$, and prolactin strongly bound to the DLB polymer. CL intensity from each protein bound to the polymer was logarithmically proportional to the amounts of each protein absorbed onto the membrane. By the mediation of avidin, the DLB polymer gave enlarged CL signal. The results in this study suggest that the binding ability of the polymer to the proteins was due to its framework, and neither luminol nor biotin moieties in the polymer, and might be caused by the comprehensive function of both electrostatic and steric complementarities.

\section{Acknowledgements}

This work was supported by grants-in-aid for Scientific Research from the Ministry of Health, Labor, and Welfare of Japan, and partly from the Ministry of Education, Culture, Sports, Science and Technology of Japan and the Global Center of Excellence Program at Nagasaki University. 
References

[1] S.D. Jayasena, Clin. Chem., 45, (1999) 1628.

[2] C.R. Ireson, and L.R. Kelland, Mol. Cancer Ther., 5 (2006) 2957.

[3] I. Surugiu, L. Ye, E. Yilmaz, A. Dzgoev, B. Danielsson, K. Mosbach, and K. Haupt, Analyst, $125(2000) 13$.

[4] K. Haupt, Anal. Chem., 75 (2003) 377.

[5] J. Svitel, I. Surugiu, A. Dzgoev, K. Ramanathan, and B. Danielsson, J. Mater. Sci. Mater. Med., $12(2001) 1075$.

[6] H. Chen, H. Zhao, L. Huang, W.R. Baeyens, J.R. Delanghe, D. He, and J. Ouyang, Electrophoresis, 26 (2005) 4260.

[7] Q. Tao, Z. Wang, H. Zhao, W.R. Baeyens, J.R. Delanghe, L. Huang, J. Ouyang, D. He, and X. Zhang, Proteomics, 7 (2007) 3481.

[8] A. Roda, M. Guarigli, E. Michelini, M. Mirasoli, and P. Pasini, Anal. Chem., 75 (2003) 463A.

[9] A.M. Powe, K.A. Fletcher, N.N. St Luce, M. Lowry, S. Neal, M.E. McCarroll, P.B. Oldham, L.B. McGown, and I.M. Warner, Anal. Chem., 76 (2004) 4614.

[10] H. Zhang, C. Smanmoo, T. Kabashima, J. Lu, and M. Kai, Angew. Chem. Int. Ed. Engl., 46 (2007) 8226.

[11] T. Satoh, K. Nishiyama, M. Nagahata, A. Teramoto, and K. Abe, Polymer. Adv. Tech., 15 (2004) 720 . 